\title{
Business Transformation on Retail Operations Due to COVID-19 and Its Impact on Indian Economy
}

\author{
Bidhan Datta ${ }^{1}$, Banantika Datta ${ }^{2}$ \\ ${ }^{1}$ Faculty of Economics \& Management, ICFAI Business School, Pune, India. \\ ${ }^{2}$ Research Scholar, Department of Economics, IIM Bangalore, India. \\ Corresponding Author: Bidhan Datta
}

\begin{abstract}
Year 2020 brought a huge challenge in business environment all over the world due to COVID19. India is not an exception and faced similar challenges which impacted heavily on the economy. India has a huge retail market being the second largest populous country in the world with huge potential and young workforce. It is an important factor for the GDP growth of any country. The aim of this paper is to compare the past, present and predict the future economic scenario by considering various factors which majorly impacted the retail market due to COVID-19. A huge transformation observed in the retail business. Buyers' choices shifted away from local retail purchases to online. Buying behaviour and consumer spending have shifted towards online purchases and also card transactions. This research also aims to study the impact of COVID-19 on Indian economy and way out of the downfall.
\end{abstract}

Key words: Buying Behaviour, Economic Growth, India, Pandemic, Retail Business

\section{INTRODUCTION}

India is among the top five largest economies in the world. Y-o-Y we could see a substantial growth in the economy. In 2019, Q2 and Q3 the gross domestic product (GDP) growth was found around $5 \%$. In the last quarter of 2019 the growth declined to $3.1 \%$. In the first quarter of financial year 2020-21 (April-June 2020), India's GDP growth suffered largest quarterly slump of $23.9 \%$ (data released by the government of India). The sharp contraction in GDP is mainly due to closure of business activity due to nationwide lockdown to curb the spread of the deadly pandemic of Coronavirus ${ }^{[1]}$. The disease, caused by the severe acute respiratory syndrome coronavirus 2(SARS-CoV-2), and the first case of COVID 19 was reported in Wuhan, China was highlighted in December 2019 in Wuhan, China. In March 2020, the World Health Organization (WHO) declared this as a pandemic ${ }^{[2]}$. COVID-19 caused a huge loss of human lives but also shattered the economy. In India all the sectors are affected and experienced a huge downfall except few essential sectors such as medicine, pharmaceutical etc. This research aims to study the impact in retail business, and shifts of consumers buying behaviour of online transaction, in India due to the recent pandemic and prediction of the future business growth.

It is also important to study the impact of the pandemic in global economy, so the impact of the same in India can be understood in better way. In the United States, within the retail sector, $43 \%$ of businesses temporarily closed their business and employment had fallen by $40 \%$. A sudden fall of 3.3 million or $22 \%$ is observed by the active business owners over the period of February to April 2020, just two months. Subsequently in May down fall of active business owners by $15 \%$ and June experienced a decline of $8 \%$. The drop in business was reported the largest on record, and losses to business activity across all industries. African American businesses were hit largest on record, experiencing a 41 
$\%$ drop in business activity. $32 \%$ downfall was observed by Latinx business owner, and Asian business owner activity dropped by $26 \%$. The number of working business owners dropped from 15.0 million in February 2020 to 11.7 million in April 2020 due to COVID-19 ${ }^{[3]}$.

The unpredicted crisis greatly hammered the economy. COVID-19 impacted the small businesses and largely effected the retail sector in India. The United States, largest economy in the world is also badly affected. In United States two industries hit particularly hard are restaurants (food) and accommodations (hotel). In March 2020, the sales declined around $80 \%$ for accommodations and around $70 \%$ for restaurants ${ }^{[4]}$. One of fastest growing country in the BRICS economy is Brazil, faced a supply and demand crisis, and will have a strong negative impact on the Brazilian GDP. This resulting in income losses and unemployment for more than $40 \%$ of Brazil's workforce ${ }^{[2]}$.

Starbucks has briefly shut the greater part of its stores in China as the fear of COVID-19 has flooded through the nation. Different games, for example, IPL and Olympics have been delayed. Production lines, restaurants, pubs, markets, flights, supermarkets, malls, universities and colleges and so forth were closed down. Dread of Covid has restricted the development in business and the mobility of people. Individuals were not in any case, going to purchase their day to day essentials and these all were affecting the economy of India and the world in general. In the initial stages, working of different online platforms, for example, Amazon, Myntra, Snapdeal, Flipkart etc. affected largely due to supply chain and restriction of lockdown but could overcome and the moment relaxations on lock down was seen.

At later stages, few businesses have done exceptionally well during this COVID19 , who are digitally transformed and are well suited to the rigors of home delivery such as Amazon, Flipkart etc. ${ }^{[5]}$. Few sectors such as retail companies are also adopting digital tools for online transactions. It is observed that the ecommerce sales have increased ${ }^{[2]}$. Due to lockdown effect, e-commerce sales increased to almost double in May 2020. It was found that the consumer expenditure on Amazon was up $60 \%$ in between May and July in 2020 from the same time frame of the last year $2019^{[6]}$.

Construction, food service, fashion, and retail are some of the sectors most affected by the pandemic ${ }^{[2]}$. Transportation services which includes taxi and some Uber drivers dropped by $22 \%{ }^{[7]}$. This study aims to understand the effect of COVID-19 on business transformation on retail, consumer behaviour on online purchases and the effect on Indian Economy.

\section{EFFECT ON RETAIL SECTOR}

COVID-19 has upset worldwide supply chains and this is creating spill over impacts all though in various degrees to different organizations. It affected the retail business as actual stores shut due to lockdown constraints, and lack of customers to remain away. Large number of workforces also went back to their native places. The Retailers' Association of India (2020) surveyed retail companies to understand the impact of COVID-19 on their businesses. More than $95 \%$ of nonfood retailers have had their stores closed ${ }^{[2]}$. Many people working in the easy-going economy in India are at a peril of falling further into poverty on account of shocking consequences of the disease. India is facing a massive decline in food chain, restaurant and food delivery businesses. Food retailers expect to earn only $56 \%$ of last year's revenues ${ }^{[2]}$. The retail industry is the second largest employer of the country and provides for a large segment of the population. To put things in perspective, small and medium-sized firms alone employ about 400-450 million people and undertake a monthly business of about $\$ 70$ billion ${ }^{[8]}$.

Lockdowns and social distancing measures influence retailers with actual 
stores more than online retailers and may eventually quicken the progressing shift from blocks and concrete to web based retailing.

\section{Retail and recreation}

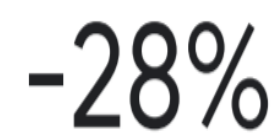

compared to baseline

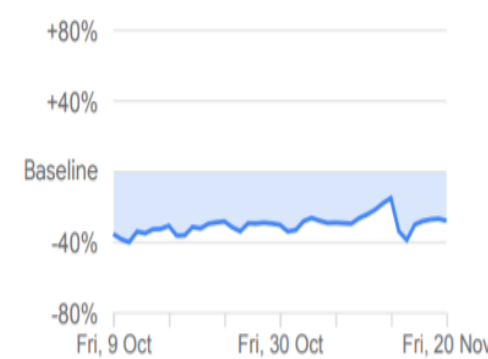

Figure 1: Mobility trends on retail and recreation

Source: COVID-19 Community Mobility Report, 20 November 2020
Mobility trends for places such as restaurants, cafés, shopping centres, theme parks, museums, libraries and cinemas.
Figure above shows the pandemic effect on retail and recreation. It shows that mobility trends declined $28 \%$ from baseline at the places such as restaurants, cafes, shopping malls, theme parks etc. A sharp fall in demand from hotels and restaurants has been observed in India and across the globe. It is getting extremely hard for cafes and restaurants to get through this pandemic. They have to bear the fixed working costs by paying rentals, utility costs and wages for workers, which is very huge and with practically zero incomes. 30\%$40 \%$ of the cafe/ restaurants are closed down. Some of them have started serving online on Zomato, Uber Eats and Swiggy to cope up with the losses and generate revenues. Food delivery service, Zomato released a report about the condition of the dining out industry that has been hit hard due to Civid-19 pandemic. Out of the $83 \%$ restaurants that are not open for business, $10 \%$ have already shut down permanently (IANS, August 19, 2020).

COVID-19 pandemic has already had a serious impact and will continue to have the effects on food processors. The industry has seen a slowdown in food processing activities because of labour and raw material inputs shortages ${ }^{[9]}$. The retail area is labour intensive, so any disturbances have lopsided business results. The area likewise depends on low-compensation and low maintenance, accessible as needs be and gig labourers that are not very much covered by customary social security measures, which further fortifies the social results of the emergency in this area. COVID-19 induced an increase in digitalisation. It is possible that online food retail could move into a new phase of growth, with newly emerging adjusted food retailing regimes ${ }_{[10]}$.

\section{REASONS FOR DOWNWARD SLOPE OF ECONOMY}

COVID-19 pandemic significantly impacts the global economic, political, environmental, socio-cultural systems. Health communication strategies and measures such as social distancing, travel and mobility bans, community lockdowns, stay at home campaigns, self- or mandatoryquarantine, curbs economic growth [11]. Manufacturing, selling, buying of products are almost frozen except essential products such as medicine and other essential food items.

One of the first consequences of the crisis has been the withdrawal of investment from countries considered to be at greatest risk. Countries that depend on exports of commodities or manufacturing goods, such as China, Mexico and Brazil, are suffering from a drop in demand. ${ }^{[2]}$. The travel industry is deeply affected; $80 \%$ of hotel rooms are empty airlines cut their workforce by $90 \%$, and tourism destinations are likely to see no profits in $2020^{[7]}$. Micro, small and medium enterprises (MSME) sector 
with limited cash flow flexibility faced hardship to survive the added cost of disruption to support themselves and their employees ${ }^{[9]}$.

There is a shortfall of aggregate demand and aggregate supply. Demands for essential products are mostly unchanged. Demand of few products like mask, sanitizer etc. and also food grains, essential retail products have been found to increase drastically. These created a demand supply gap and mostly due to panic situations during the pandemic, which leads to high price of those commodities. Due to drastic fall in aggregate demand and supply the total output decreases, causing the economic down fall. Supply-side shock is the effects of the thickening of the border on imported raw material causing a supply disruption ${ }^{[9]}$.

The sudden nationwide lockdown forced across India was the greatest on the planet, driving 1.3 billion Indians to remain inside. The lockdown limitations were forced without any planning or coordination with states ${ }^{[12]}$. States have been asked to stop large public gatherings. There was a chaos in interstate mobility of labour from workplaces to their native states. Thousands of labour force found walking thousands of kilometres to reach to their native villages. It was likewise one of the toughest lockdowns observed ever in the history.

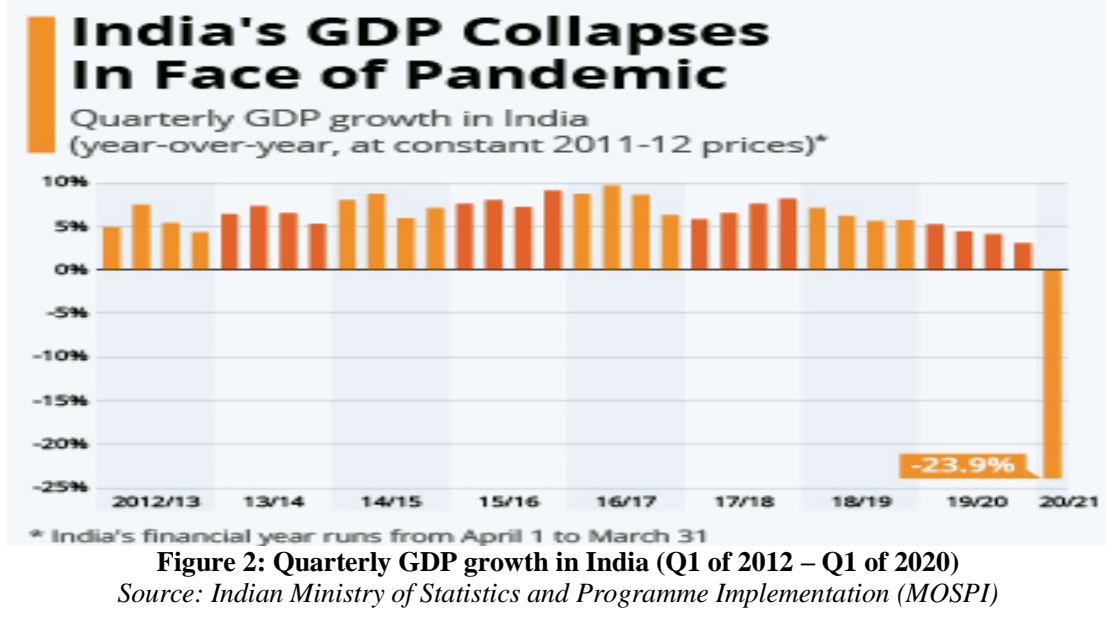

In figure 2, quarterly GDP growth of India is projected over a period of eight years from the first quarter of 2012 to first quarter of 2020 (Apr-Jun 2020). It is observed that last five years, the GDP growth in India was found around $5 \%$. In the last quarter of 2019, the growth declined to $3.1 \%$ and in the first quarter of financial year 2020-21 (April-June 2020) India's GDP growth declined to $23.9 \%$.

COVID-19 pandemic has produced anxiety, depression and stress in society ${ }^{[13]}$. Pandemic fear for mass gathering in manufacturing and other business hubs made the people cautious and started maintaining social distancing as suggested by the government. The fear also affected the buying behaviour of consumers caused the consumption to fall and the spiral effect forced the GDP to fall drastically. The perceived effectiveness of e-commerce platforms (PEEP) influences economic benefits more strongly when pandemic fear is higher ${ }^{[13]}$.

Retailers and brands face many short-term challenges, such as logistics and supply chain, the workforce, cash flow, consumer demand, sales, and marketing ${ }^{[7]}$. Health and safety of workers are also major concern for running the business. Due to large number of informal workers without an income and suspension of employment contracts, the unemployment rate will continue to rise ${ }^{[2]}$. The losses for the retail industry alone have crossed $\$ 30$ billion in the fortnight. Additionally, the losses over six months can cross a figure of about $\$ 700$ billion and the recovery period of these 
losses can be over a decade for some business ${ }^{[8]}$.

The Organization for Economic Cooperation and Development (OECD) reveals that they have cut their expectation for global growth to $2.4 \%$ from $2.9 \%$, and warns that it could fall as low as $1.5 \%{ }^{[14]}$. Early estimates have predicted that major economies will lose around 2.4 to $3.0 \%$ of their gross domestic product (GDP) during 2020 due to the COVID-19 ${ }^{[15]}$.

\section{DISCUSSION}

The economic crisis due to COVID19 pandemic is a global phenomenon. The largest economy in the world such as the United States, China and other BRICS countries are badly affected. Thus, it is essential to discuss about the effect on those strongest economy across the globe to understand better about the Indian context. The decline was particularly sharp in the Mid-Atlantic region (which includes New York City), where 54\% of firms were closed and employment was down by $\left.47 \% .{ }^{[16}\right]$. In the United States retail trade showed a decline of 108,000 business owners in April, representing $10 \%$ of February 2020 levels [3]. Retail sector and along with construction, food service, fashion are the most affected sectors ${ }^{[2]}$.

China shows that retail businesses are facing several operational and financial challenges in the country. Among the companies surveyed, $90 \%$ said that the pandemic had impacted the number of customers, especially stores and food service chains operating in shopping centres ${ }^{[2]}$. BRICS nations Brazil, Russia, India, China, and South Africa are of concern because they account for a large share of the global GDP and population ${ }^{[2]}$. According to the World Franchise Council's 2017 survey on the economic impact of franchising worldwide, India, Taiwan, and Brazil ranks among the top five countries worldwide ${ }^{[2]}$. This is particularly evident in the delivery or click \& collect models of complementary ecommerce that use their branch networks as important logistics infrastructures [10].
Consumers purchase inclined towards ecommerce platforms due to the medium's perceived health and safety benefits in contrast to those of traditional retailers. In addition to that, consumers' perceived economic benefits ${ }^{[13]}$ such as promotional discount, festival discount and online comparative study and cost savings for purchasing from e-commerce platforms make the consumers as habitual buyers.

India is not an exception. Prime Minister Narendra Modi urged the 1.3 billion citizens of India to stay indoors to protect themselves from the fast-spreading Coronavirus, with immediate barring of international flights from landing in the country and joined a growing list of countries effectively sealing their borders from overseas flights to prevent an outbreak [12].

Due to lockdown a huge impact is observed in the retail sector in India. Businesses such as retail, airlines, hospitality, sports etc. have been affected due to the pandemic effect ${ }^{[5]}$. The impacts on the economy were observed due to the sudden drops in aggregate demand and aggregate supply. Widespread shutdowns of businesses in order to control the pandemic have caused a decline in aggregate supply. Many factors were responsible for this decline such as labour migration to their native places, transportation, lack of supply chain of raw materials etc. The reduction in consumption and investment has resulted in demand decline. These impacted trade flows, sectoral performance as well as national income of the economy. ${ }^{[17]}$.

There is a huge change in the consumer behaviour on spending observed. All consumption is time bound and location bound, with time flexibility but location rigidity. Due to lockdown, the work-life boundaries became blurred as people work at home, study at home, and restrict all outdoor activities. Since the consumer is unable to go to the store, the store has to come to the consumer ${ }^{[18]}$. Online communication, online entertainment, online education and online shopping are 
seeing unprecedented growth ${ }^{[7]}$. As an example, Amazon, world's largest online retailer has benefited due to large networking, strong supply chain and online shopping facilities. The retail business model has to modify and adopt the new path as desired by consumers. Retail business should reinforce the proliferation of technological application with suppliers, retailers to build reliable platforms to deliver products and services to promote online transactions ${ }^{[13]}$. One of the major shifts of buying behaviour of consumer is observed as online purchase and delivery of product at home, as it reduces the fear of infections of COVID-19. The damage to the economy and of small businesses will be far larger if the crisis lasts for many months ${ }^{[16]}$. While some businesses are struggling, some businesses are thriving. This is true for a number of Internet-based businesses, such as those related to online entertainment, food delivery, online shopping, online education, and solutions for remote work ${ }^{[7]}$.

\section{POSSIBLE WAY OUT}

The pandemic of COVID-19 slowed down the global economy. Revival is the challenging task. All the countries are almost focusing to the same direction to announce bailout package. The largest economies of the world USA, China are also trying to find the way out. In United States majority of businesses seek funding through the Coronavirus Aid, Relief, and Economic Security (CARES) Act. ${ }^{[16]}$. Similarity is observed almost all countries across the globe. In India, government announced bailout package of Rs. 20 lakhs crores. The US announced a $\$ 2.2$ trillion stimulus on a \$20 trillion GDP base. India needs to spend more than $\$ 200$ billion or Rs. 15 lakh crores to have the same ratio of the fiscal packages to its GDP ${ }^{[19]}$. The world's second largest economy China worked to make their marketing strategies a success. They do so by identifying the typology of firms' marketing innovations based on two dimensions: i) the motivation for innovations and ii) the level of collaboration in innovations ${ }^{[7] \text {. }}$

Smt. Nirmala Sitharaman, Finance Minister of India announced relief measures as part of the economic package by the government as part of the economic package Rs 20,97,053 crore in total was announced by Prime Minister Narendra Modi for 'Atmanirbhar Bharat' (Financial Express, May 17). The southern state of Kerala announced financial help worth Rs. 200 billion ( $\$ 2.7$ billion) for citizens, making it the only Indian local administration to have announced fiscal measures of this scale ${ }^{[12]}$.

Re-optimizing of supply chains in the business model and delivery become essential to ensure there is no single point of failure. There is a requirement of deeper integration of supply chain management ${ }^{[5]}$. It might take at least 3 quarters to balance out. Without significant help, a large percentage of retailers might be bankrupt or will require critical budgetary imbuement to remain above water.

The overall effect of the pandemic on food processing economic activities and its GDP depends on the magnitude and persistence of the consequences of COVID19 on economic activities of food processors, and the investments processors [9]. The innovation of food online trade has already emerged in a niche and could now significantly affect the middle and mediating level of the sociotechnical regime [10].

There are three managerial implications from the impact of COVID-19 on consumer behaviour. i) As consumers have learnt to improvise, businesses have become more resident during the pandemic crisis. ii) Matching the equilibrium of demand and supply. iii) Consumers will go back to their old habits unless the technology they learn to use such as online purchase brings significant changes in their lives ${ }^{[18]}$. Consumers are habitual to their post purchase services and now experienced the virtual world of online purchase. People have adopted and changed their lifestyle. Consumers changed their habit, as majority 
are spending most of the time at home. Their buying behaviour have also changed and mostly impacted in retail purchase. Thus, business operations need to modify according to the consumers' shift in buying behaviour while staying at home.

As the economy and tax collections fall heavily, states demanded to permit alcohol deals to resume. The reopening had a huge purchasing of liquor and a scramble for the alcohol shops. One of the significant wellsprings of income for the states is the creation and offer of liquor. The 29 states and Union territories collected a total of ₹ 1.76 trillion through excise duty on liquor in $2019-20$ which is $16.5 \%$ higher than the collection in 2018-19 ${ }^{[20]}$.

There was a huge labour migration to their native places. They suffered a bitter experiences and hardship due to lock down. Bringing back to workplace is another challenging task that the firm is observing. The real wage rate paid by the firms needs to increase, to bring back the skilled labour force on job. The motivation and incentives to the work force is very essential to regain the faith to get the desired output level. Although the production cost will increase and thus firms will need some government subsidies. Low interest rate will also encourage the investment and will in turn increase the output level and GDP.

The pandemic has also pushed businesses across the world to rapidly operate in newer and more resilient ways ${ }^{[15]}$. Specialists have suggested a number of measures which will help retail organizations to stay utilitarian. Government should zero-in on giving more cash in the possession of the buyer, which will consequently return the framework as shopper spends increments.

In order to capitalize on the opportunity for digitization, firms need to be agile and rapidly develop capabilities that can help them survive the changes that environment imposes upon them ${ }^{[17]}$. In the long run, industries which have attempted to alter their business models in these circumstances in order to overcome the challenges to be able to sustain. Governments should reform existing economic policies to meet individuals' immediate health, food, and other basic needs; maintain political and economic stability; and protect social cohesion ${ }^{[15]}$. Thus, it is relevant to understand the buying behaviour of customers and the future trend in business model. Transformation to ecommerce business at online platform mostly in retail sector need to be strategized for sustainability.

\section{CONCLUSION}

The COVID-19 pandemic outbreak has forced many businesses to shut down. Bans on movements of transportation, truck, buses, railways, air transport, stay at home campaigns and the lockdown forced the economy to fall. Huge amount of labour movements is observed from the workplaces to their native places due job loss, leading to an unprecedented disruption in many sectors. Concept of work from home is experienced in a greater extent wherever possible. Manufacturing sectors suffered due the nature of job and physical presence of workforce. Buying behaviour of consumers are also shifted towards online shopping. Consumers started using cards/ online transfer of payment rather than cash transaction. However, rural areas and the poor or people are not user friendly about online shopping faced greater difficulties. E-commerce sectors are noticed gradually picking up its sales after relaxation of lockdown. Retailers have faced many shortterm challenges. Consumers were not allowed to shop freely due to lockdown and certain restrictions. Shopping malls were also closed. There was a disruption in the supply chain, the workforce, sales and cash flow and in turn nation faced a great economic down fall.

Government has already taken few decisions such as economics package of 20 lakhs crores, 'Atmanirbhar Bharat', reduction in interest rate, so that the investment can be increased. The spiral effect of injection will help to recover the 
GDP downfall in a faster rate. Economy of India will recover gradually, and it may take more than a year to back to its normal phase. Government initiatives to help the firms, providing subsidies will also help to improve the situation. Increase in government consumption expenditure and supporting to small, medium and micro organisation will further help to boost the economy. It could be suggested that there is a need to change the business model. More collaborative approach between firms will help to certain extent. Firms need to motivate their employee and the $\mathrm{R} \& \mathrm{D}$ teams should continuously work on innovations as per the strategical changes.

Acknowledgement: None

Conflict of Interest: None

\section{Source of Funding: None}

\section{REFERENCES}

1. TOI, "GDP contracts by record $23.9 \%$ in Q1 against 3.1\% growth in previous quarter," The Times of India, New Delhi, August 31, 2020.

2. A. I. Bretas VPG, "The impact of COVID-19 on franchising in emerging," wileyonlinelibrary.com/journal/joe, 2020; 39(6):6-16.

3. R. W. Fairlie, "The Impact of COVID19 on Small Business Owners:," NBER, Working Paper 27309, 2020; 1-20.

4. A. Dunn, "Measuring the Effects of the COVID-19 Pandemic on," Bureau of Economic Analysis, Working Paper Series, WP2020-5, 2020; 1-22.

5. S. Krishnamurthy, "The future of business education: A commentary in the shadow of the Covid-," Journal of Business Research, 2020; 117:1-5.

6. A. Semuels, "Many Companies Won't Survive the Pandemic. Amazon Will Emerge Stronger Than Ever," TIME, Business, 2020.

7. N. Donthu, "Effects of COVID-19 on business and research," Journal of Business Research, 2020; 117: 284-289.
8. S. Vakharia, "Can India's Retail Industry Survive The Covid-19 Lockdown," Magzter, 2020.

9. G. Hailu, "Economic thoughts on COVID-19 for Canadian food processors," Cand J Agr Econ, 2020; 68:163-169.

10. P. Dannenberg, "Digital Transition by COVID-19 Pandemic?," Tijdschrift voor Economische en Sociale Geografie, 2020; 111(3):543-560.

11. M. Sigala, "Tourism and COVID-19: Impacts and implications for advancing and," Journal of Business Research, 2020; 117:312-321.

12. A. C. a. A. R. Chowdhury, "Modi Asks 1.3 Billion Indians to Stay Indoors in Virus Fight," Bloomberg, 2020.

13. L. T. T. Tran, "Managing the effectiveness of e-commerce platforms in a pandemic," Journal of Retailing and Consumer Services, 2020; 58:1-9.

14. S. Khurana, "Impact of Covid-19 on the Indian Economy," The Economic Times, BFSI, May 07, 2020.

15. S. Verma, "Investigating the emerging COVID-19 research trends in the field of business and management: A bibliometric analysis approach," Journal of Business Research, 2020; 118:253261.

16. A. W. Bartik, "The impact of COVID19 on small business outcomes," PNAS, 2020; 117(30):17656-17666.

17. P. Seetharaman, "Business models shifts: Impact of Covid-19," International Journal of Information Management, 2020; 54:1-4.

18. J. Sheth, "Impact of Covid-19 on consumer behavior: Will the old habits return or die?," Journal of Business Research, 2020; 117:280-283.

19. M. Moitra, "View: Government should unveil stimulus package to deal with coronavirus fallout," View: Government should unveil stimulus package to deal with coronavirus fallout, E-Paper, 2020.

20. R. Agarwal, "How Alcohol Industry Is Contributing To Indian Economy 
Bidhan Datta et.al. Business transformation on retail operations due to COVID-19 and its impact on Indian economy.

Amidst Corona Crisis," Magzter Digital

Newsstand, Ambrosia, 2020.

21. S. V. a. A. Gustafssonb, "Investigating the emerging COVID-19 research trends in the field of business and management: A bibliometric analysis approach," Journal of Business Research, 2020; 118:253-261.
How to cite this article: Datta B, Datta B. Business transformation on retail operations due to COVID-19 and its impact on Indian economy. International Journal of Research and Review. 2021; 8(4): 110-118. DOI: https://doi.org/10.52403/ijrr.20210416 